\title{
PENGARUH SISTEM INTEGRASI TEBU-SAPI TERHADAP PRODUKSI TEBU, SAPI, DAN PENDAPATAN PETANI DI KABUPATEN GORONTALO, PROVINSI GORONTALO
}

\author{
Sriyani Wahyuni Tangahu ${ }^{1}$, Sri Hartoyo ${ }^{2}$, dan Anna Fariyanti ${ }^{2}$ \\ 'Mahasiswa Ilmu Ekonomi Pertanian, Sekolah Pascasarjana, Institut Pertanian Bogor \\ ${ }^{2}$ Fakultas Ekonomi dan Manajemen, Institut Pertanian Bogor
}

\section{Email: riritangahu@gmail.com}

ABSTRAK. Tujuan dari penelitian ini adalah menganalisis pengaruh sistem integrasi tebu-sapi terhadap produksi tebu, produksi sapi, dan pendapatan petani tebu. Data yang digunakan adalah data primer yang bersumber dari wawancara langsung kepada 59 petani tebu yang memiliki sapi. Analisis yang dilakukan yaitu analisis fungsi produksi Cobb-Douglas dan analisis fungsi pendapatan. Hasil penelitian menunjukkan bahwa sistem integrasi tebu-sapi memberikan pengaruh negatif terhadap produksi tebu dan produksi sapi. Sistem integrasi tebu-sapi, tidak signifikan mempengaruhi peningkatan pendapatan petani.

Kata kunci: tenaga kerja, pakan hijauan, pakan konsentrat, dummy sistem integrasi tebu-sapi, pendapatan

\section{THE EFFECT OF INTEGRATED FARMING SYSTEM OF SUGARCANE,BEEF CATTLE, TO SUGARCANE AND BEEF CATTLE PRODUCTION AND FARMER INCOME IN GORONTALO PROVINCE}

ABSTRACT. This study aims to analyze the effect of sugarcane-beef cattle integration system to sugarcane and cattle production, and sugarcane farmers income. The primary data are used in this study, based on the results of interviews to 59 cane farmers who have beef cattle. The research methods are the Cobb-Douglas production function and income function. The results showed that sugarcane-beef cattle integration system has negative affect to the production of sugarcane and beef cattle, and this does not significantly affect to the increase of farmers income

Keywords: sugarcane, beef cattle, integrated farming system, production, income

\section{PENDAHULUAN}

Lahan merupakan salah satu sumberdaya yang terbatas sehingga kegiatan ekstensifikasi, khususnya pada lahan-lahan optimal tidak dapat dilakukan untuk meningkatkan produksi pertanian. Keterbatasan sumberdaya lahan tidak hanya dari segi luasan tapi juga kualitas seperti penurunan produktivitas lahan. Oleh karena itu, peningkatan produksi pertanian dapat dicapai dengan kegiatan intensifikasi (Kariyasa, 2005 dan Handayani, 2009).

Salah satu kegiatan intensifikasi yang dapat dilakukan yaitu sistem integrasi tanaman-ternak. Sistem integrasi tanaman-ternak yaitu kegiatan mengintegrasikan tanaman dengan ternak, dimana limbah dari satu produk pertanian digunakan sebagai input bagi produk pertanian yang lain. Oleh karena itu, terjadi sinergi antara keduanya sehingga hampir tidak ada sumberdaya yang terbuang atau zero waste (Devendra et al., 1997). Kegiatan mengintegrasikan tanaman dengan ternak telah banyak dilaksanakan, baik itu integrasi antara tanaman pangan, perkebunan, hortikultura, dengan ternak sapi, kambing, ayam, dan ternak lainnya. Bentuk kegiatan integrasi tanamanternak merupakan program dari pemerintah yang dilakukan di beberapa tempat (Direktorat Jenderal Peternakan dan Kesehatan, Hewan 2012).

Kegiatan sistem integrasi tanaman-ternak memberikan keuntungan, seperti peningkatan produksi dan pendapatan petani. Peningkatan produksi terjadi baik pada tanaman maupun ternak sehingga penerimaan dan pendapatan petani juga meningkat. Peningkatan pendapatan petani bukan hanya karena peningkatan produksi utama tanaman dan ternak, tapi juga karena peningkatan produksi limbah yang dapat diolah kemudian dijual sehingga petani memperoleh pendapatan tambahan (Khairiah dan Wasito, 2007 dan Priyanti, 2007).

Kabupaten Gorontalo merupakan salah satu wilayah yang mendapatkan bantuan program sistem integrasi yaitu sistem integrasi tebu-sapi, yang dilaksanakan pada tahun 2009. Bentuk bantuan dari program ini yaitu pemerintah memberikan bantuan berupa uang tunai kepada kelompok tani tebu yang telah dipilih, kemudian bantuan tersebut digunakan untuk pengadaan sapi. Program sistem integrasi tebu-sapi perlu dilakukan di Gorontalo, karena melihat potensi tanaman tebu yang diperkirakan setiap tahunnya dapat menghasilkan pucuk tebu segar sebanyak 9029 ton yang dapat dijadikan pakan bagi ternak sapi (Dinas Pekebunan dan Peternakan Provinsi Gorontalo, 2009).

Program sistem integrasi tebu-sapi yang dilaksanakan oleh pemerintah, diharapkan dapat meningkatkan produksi dan pendapatan petani. Berkaitan dengan hal tersebut, maka dapat dilihat perkembangan produktivitas tebu dan populasi sapi di Provinsi Gorontalo yang disajikan pada Tabel 1. Berdasarkan Tabel 1, rata-rata produktivitas tebu dari tahun 2008 hingga 2012 mengalami penurunan sebesar 7,92 persen. Sama halnya dengan produktivitas tebu, rata-rata populasi sapi pada tahun 2008 hingga 2012 juga mengalami penurunan sebesar 2,2 persen. Penurunan produktivitas tebu dan populasi sapi tersebut akan berpengaruh terhadap pendapatan yang diterima petani. 
Tabel 1. Perkembangan Produktivitas Tebu dan Populasi Sapi di Provinsi Gorontalo, 2008-2012

\begin{tabular}{ccccc}
\hline Tahun & $\begin{array}{c}\text { Produktivitas } \\
\text { Tebu (ton/ha) }\end{array}$ & $\begin{array}{c}\text { Perkem } \\
\text { bangan } \\
(\%)\end{array}$ & $\begin{array}{c}\text { Populasi } \\
\text { Sapi (ekor) }\end{array}$ & $\begin{array}{c}\text { Perkembangan } \\
(\%)\end{array}$ \\
\hline 2008 & 44,87 & & 227.707 & \\
2009 & 36,69 & $-18,23$ & 240.676 & 5,69 \\
2010 & 45,09 & 22,89 & 253.432 & 5,3 \\
2011 & 22,18 & $-50,81$ & 183.876 & $-27,45$ \\
2012 & 27,11 & 22,22 & 202.990 & 10,4 \\
\hline
\end{tabular}

Sumber: Direktorat Pengembangan Potensi Daerah BKPM (2014) dan BPS Provinsi Gorontalo (2012)

Berdasarkan kondisi tersebut maka apakah sistem integrasi tebu-sapi berpengaruh terhadap produktivitas tebu, populasi sapi, dan pendapatan petani. Oleh karena itu, penelitian ini bertujuan untuk menganalisis pengaruh sistem integrasi tebusapi terhadap produksi tebu, produksi sapi, dan pendapatan petani.

\section{METODE}

Penelitian dilaksanakan di Desa Sidomukti, Desa Parungi, Desa Potanga, Desa Molohu, Desa Lakeya, dan Desa Sidoharjo. Keenam desa yang menjadi lokasi penelitian terletak di Kabupaten Gorontalo yang merupakan salah satu kabupaten sentra perkebunan tebu. Desa yang terpilih sebagai desa sampel merupakan desa dengan luas lahan tebu terbesar. Jumlah desa yang ada di Kabupaten Gorontalo yaitu 18 desa dan 30 persen dari jumlah desa tersebut dijadikan sebagai desa sampel. Populasi petani dalam penelitian ini adalah petani tebu yang memiliki sapi yang berada di enam desa sampel. Petani yang dijadikan sampel dalam penelitian ini berjumlah 59 petani yang dipilih secara acak sederhana, terdiri dari 47 petani tebu yang menerapkan sistem integrasi tebu-sapi dan 12 petani tebu yang tidak menerapkan sistem integrasi tebu-sapi.

Data yang digunakan dalam penelitian ini adalah data primer dan data sekunder. Data primer bersumber dari petani yang dikumpulkan melalui wawancara langsung kepada petani tebu yang memiliki sapi, berdasarkan daftar pertanyaan. Data sekunder diperoleh dari pabrik gula (PT.PG.Gorontalo), koperasi petani tebu rakyat (KPTR), dan instansi terkait lainnya seperti Dinas Perkebunan dan Peternakan Provinsi Gorontalo dan Badan Pusat Statistik Provinsi Gorontalo.

Analisis yang dilakukan pada penelitian ini yaitu analisis fungsi produksi Cobb-Douglas dan analisis fungsi pendapatan. Analisis fungsi produksi CobbDouglas terdiri dari analisis untuk produksi tebu dan produksi sapi. Analisis ini diperlukan untuk menganalisis pengaruh sistem integrasi tebu-sapi terhadap produksi tebu dan sapi. Analisis fungsi produksi tebu dan sapi dilakukan secara terpisah karena input-input yang digunakan untuk produksi tebu dan sapi berbeda.

Fungsi produksi Cobb-Douglas untuk produksi tebu yaitu: $\ln Y_{1}=\ln \beta_{0}+\beta_{1} \ln X_{1}+\beta_{2} \ln X_{2}+\beta_{3} \ln X_{3}+\beta_{4} X_{4}+\varepsilon_{i}$

dimana: $\mathrm{Y} 1=$ produkivitas tebu (ton $/ \mathrm{ha}), \mathrm{X}_{1}=$ jumlah pupuk ponska $(\mathrm{kg} / \mathrm{ha}), \mathrm{X}_{2}=$ jumlah herbisida (liter/ha), $X_{3}=$ nilai tenaga kerja (Rp/ha), $X_{4}=$ dummy penerapan sistem integrasi tebu-sapi (1 untuk petani yang menerapkan sistem integrasi tebu-sapi dan 0 untuk petani yang tidak menerapkan sistem integrasi tebu-sapi), $\beta_{1}$ hingga $\beta_{4}=$ koefisien parameter dari masing-masing variabel input produksi tebu. Tanda yang diharapkan untuk semua koefisien parameter adalah positif.

Fungsi produksi Cobb-Douglas untuk produksi sapi yaitu:

$$
\ln Y_{2}=\ln \beta_{0}+\beta_{1} \ln Z_{1}+\beta_{2} \ln Z_{2}+\beta_{3} \ln Z_{3}+\beta_{4} Z_{4}+\varepsilon_{i}
$$

dimana: $\mathrm{Y}_{2}=$ nilai sapi $(\mathrm{Rp}), \mathrm{Z}_{1}=$ nilai pakan hijauan dan konsentrat (Rp), $Z_{2}=$ nilai obat sapi (Rp), $Z_{3}=$ nilai tenaga kerja $(R p), Z_{4}=$ dummy penerapan sistem integrasi tebu-sapi (1 untuk petani yang menerapkan sistem integrasi tebu-sapi dan 0 untuk petani yang tidak menerapkan sistem integrasi tebusapi), $\beta_{1}$ hingga $\beta_{4}=$ koefisien parameter dari masingmasing variabel input produksi sapi. Tanda yang diharapkan untuk semua koefisien parameter adalah positif.

Selain analisis fungsi produksi, analisis fungsi pendapatan juga dilakukan pada penelitian ini. Analisis fungsi pendapatan yaitu berupa analisis fungsi pendapatan logaritma yang dilakukan untuk melihat pengaruh sistem integrasi tebu-sapi terhadap pendapatan petani tebu. Bentuk fungsi pendapatan adalah sebagai berikut.

$\ln C=\ln \beta_{0}+\beta_{1} \ln L L+\beta_{2} \ln J S+\beta_{3} \ln T K D K+\beta_{4} D S I+\varepsilon_{i}$ (3)

dimana: $\mathrm{C}=$ total pendapatan petani tebu dari usahatani tebu dan sapi (Rp), LL = luas lahan tebu (ha), JS = jumlah ternak sapi yang dimiliki petani (ekor), TKDK = jumlah tenaga kerja dalam keluarga (orang), DSI = dummy sistem integrasi tebu-sapi (1 untuk petani yang menerapkan sistem integrasi tebu-sapi dan 0 untuk petani yang tidak menerapkan sistem integrasi tebu-sapi), $\beta_{1}$ hingga $\beta_{4}=$ koefisien parameter dari masing-masing variabel dalam model pendapatan. Tanda yang diharapkan untuk semua koefisien parameter adalah positif.

\section{HASIL DAN PEMBAHASAN}

Input produksi yang digunakan untuk memproduksi tebu dan sapi adalah berbeda untuk masing-masing produk tersebut. Perbedaan juga terjadi pada penggunaan input produksi oleh petani yang melaksanakan sistem integrasi tebu-sapi dan tidak melaksanakan sistem integrasi tebu-sapi. Berikut disajikan perbedaan penggunaan input produksi tebu dan sapi (Tabel 2 dan 4).

Input produksi yang digunakan untuk memproduksi tebu yaitu luas lahan, pupuk ponska, herbisida, tenaga kerja dalam keluarga, dan tenaga kerja luar keluarga. Penggunaan input produksi luas lahan merupakan persentase dari jumlah keseluruhan luas lahan tebu yang diusahakan oleh petani. Seperti yang ditunjukkan pada Tabel 2, persentase penggunaan luas lahan adalah lebih tinggi untuk 
petani yang melaksanakan sistem integrasi tebu-sapi dibandingkan dengan petani yang tidak melaksanakan sistem integrasi tebu-sapi.

Tabel 2 Perbedaan Penggunaan Input Produksi Tebu antara Petani Pelaksana Sistem Integrasi Tebu-Sapi dan Bukan Pelaksana Sistem Integrasi Tebu-Sapi

\begin{tabular}{lcc}
\hline \multicolumn{1}{c}{ Input Produksi } & \multicolumn{2}{c}{ Penggunaan Input Produksi Tebu(\%) } \\
& $\begin{array}{c}\text { Petani yang Melaksanakan } \\
\text { Sistem Integrasi Tebu-Sapi }\end{array}$ & $\begin{array}{c}\text { Petani yang tidak } \\
\text { Melaksanakan Sistem } \\
\text { Integrasi Tebu-Sapi }\end{array}$ \\
\hline Luas Lahan & 54,13 & 45,87 \\
Pupuk ponska & 52,28 & 47,72 \\
Herbisida & 46,69 & 53,31 \\
$\begin{array}{l}\text { Tenaga kerja dalam } \\
\text { keluarga } \\
\text { Tenaga kerja luar }\end{array}$ & 47,4 & 52,6 \\
keluarga & 48 & 52 \\
\hline
\end{tabular}

Lahan tebu di lokasi penelitian relatif merupakan lahan kering. Luas lahan tebu maksimum yaitu 5,08 hektar dan luas lahan tebu minimum yaitu 0,26 hektar dengan rata-rata 1,14 hektar. Jumlah petani yang memiliki luas lahan di atas 1 hektar sejumlah 28 petani yang jumlahnya lebih sedikit daripada petani yang memiliki luas lahan di bawah 1 hektar. Persentase petani yang melaksanakan sistem integrasi tebusapi untuk klasifikasi luas lahan di atas 1 hektar, sebesar 48,94 persen yang berarti petani pada klasifikasi ini lebih banyak yang melaksanakan sistem integrasi daripada yang tidak melaksanakan sistem integrasi. Demikian juga halnya pada klasifikasi luas lahan di bawah 1 hektar, persentase petani yang melaksanakan sistem integrasi lebih banyak daripada petani yang tidak melaksanakan sistem integrasi tebu-sapi yaitu sebesar 51,06 persen (Tabel 3).

Tabel 3. Perbedaan Luas Lahan Tebu antara Petani yang Melaksanakan Sistem Integrasi Tebu-Sapi dan Tidak Melaksanakan Sistem Integrasi Tebu-Sapi

Penggunaan input produksi pupuk ponska, herbisida, dan tenaga kerja dalam keluarga merupakan persentase dari penggunaan input-input tersebut dalam setiap satuan hektar luas lahan. Persentase

\begin{tabular}{|c|c|c|c|c|c|}
\hline \multirow{2}{*}{ No. } & \multirow{2}{*}{$\begin{array}{l}\text { Klasifikasi Rata- } \\
\text { rata Luas Lahan } \\
\text { Tebu (hektar) }\end{array}$} & \multicolumn{2}{|c|}{ Frekuensi Petani Tebu (orang) } & \multicolumn{2}{|c|}{ Persentase (\%) } \\
\hline & & Ikut Integrasi & $\begin{array}{l}\text { Tidak ikut } \\
\text { integrasi }\end{array}$ & $\begin{array}{c}\text { Ikut } \\
\text { Integrasi }\end{array}$ & $\begin{array}{l}\text { Tidak ikut } \\
\text { integrasi }\end{array}$ \\
\hline 1. & $<1$ & 24 & 7 & 51,06 & 58,33 \\
\hline 2. & $\geq 1$ & 23 & 5 & 48,94 & 41,67 \\
\hline
\end{tabular}

penggunaan pupuk ponska adalah lebih tinggi untuk petani yang melaksanakan sistem integrasi tebusapi jika dibandingkan dengan petani yang tidak melaksanakan sistem integrasi tebu-sapi, sedangkan persentase penggunaan herbisida, tenaga kerja dalam keluarga, dan tenaga kerja luar keluarga adalah lebih tinggi untuk petani yang tidak melaksanakan sistem integrasi tebu-sapi.

Inputproduksiyang digunakanuntukmemproduksi sapi yaitu pakan hijauan, pakan konsentrat, obat sapi, dan tenaga kerja dalam keluarga. Penggunaan semua input produksi sapi adalah persentase dari rata-rata penggunaan input produksi oleh petani untuk setiap ekor sapi. Persentase penggunaan semua input produksi adalah lebih tinggi pada petani yang melaksanakan sistem integrasi tebu-sapi.
Tabel 4. Perbedaan Penggunaan Input Produksi Sapi antara Petani Pelaksana Sistem Integrasi Tebu-Sapi dan Bukan Pelaksana Sistem Integrasi Tebu-Sapi

\begin{tabular}{|c|c|c|}
\hline \multirow[b]{2}{*}{ InputProduksi } & \multicolumn{2}{|c|}{ Rata-rata Penggunaan Input Produksi Sapi (\%) } \\
\hline & $\begin{array}{l}\text { Petani yang Melaksanakan Sistem P } \\
\text { Integrasi Tebu-Sapi }\end{array}$ & $\begin{array}{l}\text { Petaniyang tidak Melaksanakan } \\
\text { Sistem Integrasi Tebu-Sapi }\end{array}$ \\
\hline Pakan hijauan & 52,51 & 47,49 \\
\hline Pakan konsentrat & 52,6 & 47,4 \\
\hline ObatSapi & 59,99 & 40,01 \\
\hline Tenaga kerja dalam keluarga & 50,8 & 49,2 \\
\hline
\end{tabular}

Pengaruh Sistem Integrasi Tebu-Sapi terhadap Produksi Tebu dan Sapi

Produksi tebu dipengaruhi oleh variabel input pupuk ponska, herbisida, tenaga kerja dan dummy penerapan sistem integrasi tebu-sapi. Hasil pendugaan model produksi tebu disajikan pada Tabel 5. Berdasarkan hasil pendugaan tersebut, nilai koefisien determinasi yang ditunjukkan dengan nilai $\mathrm{R}^{2}$ yaitu sebesar 0,832 , menunjukkan bahwa 83,2 persen variasi produksi tebu dapat dijelaskan oleh semua variabel yang ada dalam model fungsi produksi tebu.

Produksi tebu yang dimaksud dalam analisis ini adalah produksi tebu per hektar lahan tebu (produktivitas), demikian juga dengan penggunaan input produksi dalam analisis ini adalah penggunaan input produksi per hektar lahan tebu. Oleh karena itu, berdasarkan hasil pendugaan koefisien, total koefisien dari variabel pupuk ponska, herbisida, dan tenaga kerja sebesar 0,943, sehingga variabel luas lahan memberikan pengaruh sebesar 0,057 terhadap peningkatan produksi tebu.

Variabel selain luas lahan yaitu pupuk ponska, herbisida, tenaga kerja, dan dummy penerapan sistem integrasi tebu-sapi, semua variabel tersebut secara signifikan memberikan pengaruh positif terhadap produksi tebu, kecuali dummy penerapan sistem integrasi tebu-sapi. Demikian juga yang disampaikan oleh Shehu et al. (2010) dan Musa et al. (2011), bahwa variabel pupuk, herbisida, dan tenaga kerja memberikan pengaruh yang positif terhadap produksi tanaman. Pada fungsi produksi tebu Cobb-Douglas, nilai koefisien masing-masing variabel juga menunjukkan nilai elastisitas dari masingmasing variabel tersebut. Berkaitan dengan hal tersebut, variabel tenaga kerja yang memiliki nilai koefisien paling besar dibandingkan dengan variabel lainnya berarti memiliki nilai elastisitas paling besar juga, sehingga penambahan ataupun pengurangan penggunaan variabel tenaga kerja akan memberikan peningkatan ataupun penurunan terhadap produksi tebu paling besar, jika dibandingkan dengan perubahan variabel input lainnya.

Tabel 5. Hasil Pendugaan Model Produksi Tebu

\begin{tabular}{lllll}
\hline \multicolumn{1}{c}{ Variabel Input } & $\begin{array}{l}\text { Parameter } \\
\text { Koefisien }\end{array}$ & Nilait & Nilai p & VIF \\
\hline Konstanta & $-8,17$ & $-6,88$ & 0 & \\
Pupuk Ponska $\left(\mathrm{X}_{1}\right)$ & 0,176 & 2,178 & 0,034 & 1,84 \\
Herbisida $\left(\mathrm{X}_{2}\right)$ & 0,009 & 1,77 & 0,083 & 1,78 \\
Tenaga Kerja $\left(\mathrm{X}_{3}\right)$ & 0,758 & 8,447 & 0 & 2,18 \\
& & & & \\
Dummy Penerapan Sistem & $-0,047$ & $-1,29$ & 0,202 & 1,03 \\
Integrasi Tebu-Sapi $\left(\mathrm{X}_{4}\right)$ & & & & \\
Koefisien Determinasi $\left(\mathrm{R}^{2}\right)$ & 0,832 & & & \\
\hline
\end{tabular}


Berbeda dengan variabel lainnya, variabel dummy penerapan sistem integrasi memiliki koefisien yang negatif. Variabel dummy penerapan sistem integrasi yang dimaksud untuk model produksi tebu ini adalah penggunaan pupuk kandang untuk usahatani tebu. Hasil pendugaan menunjukkan bahwa produksi tebu dari petani yang menerapkan sistem integrasi tebusapi lebih rendah dibandingkan dengan produksi tebu dari petani yang tidak menerapkan sistem integrasi tebu-sapi, namun hasil ini tidak signifikan. Tanda koefisien negatif tersebut bukan berarti pupuk kandang tidak perlu digunakan sehingga tidak perlu adanya sistem integrasi tebu-sapi. Terdapat faktor lain yang bisa menjelaskan kondisi tersebut seperti kondisi pupuk kandang yang digunakan untuk memupuk lahan tebu. Pupuk kandang yang digunakan untuk memupuk lahan tebu, tidak diolah terlebih dahulu dengan serangkaian proses pengolahan pupuk. Puastuti (2007), menjelaskan bahwa pemberian bahan organik yang belum mengalami dekomposisi dengan sempurna pada tanaman, kurang memberi manfaat bahkan dapat mengakibatkan efek negatif.

Selain model produksi tebu, model produksi sapi juga perlu dijelaskan dalam penelitian ini. Hasil pendugaan model produksi sapi disajikan pada Tabel 6. Nilai koefisien determinasi yang ditunjukkan dengan nilai $\mathrm{R}^{2}$ yaitu sebesar 0,973 , menunjukkan bahwa 97,3 persen variasi produksi sapi dapat dijelaskan oleh semua variabel yang ada dalam model fungsi produksi sapi. Produksi sapi dipengaruhi oleh variabel input pakan (hijauan dan konsentrat), obat sapi, tenaga kerja, dan dummy penerapan sistem integrasi tebu-sapi.

Tabel 6. Hasil Pendugaan Model Produksi Sapi

\begin{tabular}{ccccc}
\hline Variabel Input & Parameter Koefisien & Nilai & Nilai p & VIF \\
\hline Konstanta & 3,804 & 1,428 & 0,162 & \\
Pakan hijauan+konsentrat $\left(\mathrm{Z}_{1}\right)$ & 0,478 & 36,23 & 0 & 1,1 \\
Obat Sapi $\left(\mathrm{Z}_{2}\right)$ & 0,012 & 2,45 & 0,019 & 1,02 \\
Tenaga Kerja $\left(\mathrm{Z}_{3}\right)$ & 0,345 & 1,992 & 0,054 & 1,08 \\
Dummy Penerapan Sistem & $-0,258$ & $-2,299$ & 0,027 & 1,03 \\
Integrasi Tebu-Sapi $\left(\mathrm{Z}_{4}\right)$ & & & & \\
Koefisien Determinasi $\left(\mathrm{R}^{2}\right)$ & 0.973 & & & \\
\hline
\end{tabular}

Semua variabel input tersebut berpengaruh secara signifikan terhadap produksi sapi. Ketiga variabel input memberikan pengaruh yang positif terhadap produksi sapi, kecuali dummy penerapan sistem integrasi tebusapi. Variabel pakan (hijauan dan konsentrat), memiliki nilai koefisien (nilai elastisitas) terbesar dibandingkan dengan variabel yang lain, hal ini menunjukkan bahwa perubahan variabel pakan akan memberikan pengaruh paling besar bagi perubahan produksi sapi, seperti yang dijelaskan oleh Achmad (2011). Berbeda dengan variabel pakan, variabel dummy penerapan sistem integrasi tebu-sapi memiliki tanda koefisien yang negatif. Variabel dummy penerapan sistem integrasi tebu-sapi yang dimaksud dalam model produksi sapi ini yaitu penggunaan pucuk tebu sebagai pakan sapi. Berdasarkan hasil tersebut, maka dapat dikatakan bahwa produksi sapi dari petani yang menggunakan pucuk tebu lebih rendah dibandingkan dengan produksi sapi dari petani yang tidak menggunakan pucuk tebu. Namun bukan berarti, pucuk tebu tidak dapat dijadikan pakan bagi sapi. Pucuk tebu merupakan limbah perkebunan yang dapat dijadikan sebagai pakan alternatif bagi ternak sapi, namun tidak dapat mensubstitusi pakan hijauan rumput yang hingga sekarang masih menjadi pakan utama bagi ternak sapi.

Limbah perkebunan seperti limbah pucuk tebu dan limbah pertanian lainnya, dapat dijadikan sebagai pakan alternatif melalui serangkaian pengolahan pakan (Indraningsih et al., 2006). Penggunaan pucuk tebu sebagai pakan ternak hanya dapat dilakukan pada saat musim panen tebu. Selain itu karakteristik dari pucuk tebu yang mudah rusak dalam penyimpanan, kadar protein dan tingkat kecernaan yang rendah dari pucuk tebu yang tidak diolah, sehingga hal-hal tersebut menjadi kendala dalam penggunaan limbah pucuk tebu sebagai pakan. Oleh karena itu, diperlukan pengolahan dan pengawetan limbah tebu (Retnani et al., 2009).

Pucuk tebu yang digunakan sebagai pakan ternak sapi tidak diolah terlebih dahulu, sehingga mengindikasikan bahwa hal tersebut sebagai penyebab pengaruh negatif dari penggunaan pucuk tebu terhadap produksi sapi. Pengolahan pakan dan pupuk tidak dilakukan oleh petani karena masih sangat minim pengetahuan tentang teknologi pengolahan pakan, demikian pun tentang teknologi pengolahan pupuk. Hal ini disebabkan karena kurangnya pendampingan dari pemerintah untuk membimbing petani dalam pelaksanaan sistem integrasi tebu-sapi, khususnya bimbingan dalam penguasaan teknologi pengolahan pakan dan pupuk.

Pengaruh Sistem Integrasi Tebu-Sapi terhadap Pendapatan Petani

Sistem integrasi tebu-sapi merupakan inovasi teknologi. Penerapan teknologi pada usahatani dapat meningkatkan pendapatan (Kusnadi, 2008 dan Hartoyo, 2013). Berdasarkan Tabel 7, pendapatan petani yang melaksanakan sistem integrasi tebu-sapi lebih tinggi daripada petani yang tidak melaksanakan sistem integrasi tebu-sapi. Penelitian sebelumnya tentang sistem integrasi tanaman-ternak, menjelaskan bahwa pelaksanaan sistem integrasi tersebut dapat membantu petani untuk meningkatkan pendapatannya (Asmara, 2002, Howara, 2004 dan Elly et al., 2008).

Tabel 7. Perbedaan Pendapatan antara Sistem Integrasi TebuSapi dan Non Sistem Integrasi Tebu-Sapi

\begin{tabular}{lcccc}
\hline & \multicolumn{2}{c}{ Nilai Rata-rata (Juta Rp) } & \multicolumn{2}{c}{ Persentase (\%) } \\
& $\begin{array}{c}\text { Sistem } \\
\text { Integrasi }\end{array}$ & $\begin{array}{c}\text { Non Sistem } \\
\text { Integrasi }\end{array}$ & $\begin{array}{c}\text { Sistem } \\
\text { Integrasi }\end{array}$ & $\begin{array}{c}\text { Non Sistem } \\
\text { Integrasi }\end{array}$ \\
\hline A.Total Penerimaan & 31,2 & 28,61 & & \\
Penerimaan Tebu (per ha) & 23,41 & 21,29 & 75,02 & 74,43 \\
Penerimaan Sapi (per ekor) & 7,79 & 7,32 & 24,98 & 25,57 \\
B.Total Biaya Produksi & 11,07 & 10,76 & & \\
Biaya Produksi Tebu(per ha) & 5,76 & 5,86 & 52,02 & 54,42 \\
Biaya Produksi Sapi (per ekor) 5,31 & 4,9 & 47,98 & 45,58 \\
C.Total Pendapatan & 20,13 & 17,84 & & \\
Pendapatan Tebu (perha) & 17,65 & 15,43 & 87,68 & 86,49 \\
Pendapatan Sapi (perekor) & 2,48 & 2,41 & 12,32 & 13,51 \\
\hline
\end{tabular}


Sama halnya dengan pendapatan, penerimaan dari petani yang melaksanakan sistem integrasi tebusapi juga lebih tinggi daripada petani yang tidak melaksanakan sistem integrasi tebu-sapi. Penerimaan dari usahatani tebu baik di petani yang melaksanakan sistem integrasi tebu-sapi maupun petani yang tidak melaksanakan sistem integrasi tebu-sapi adalah lebih tinggi daripada penerimaan yang bersumber dari usaha sapi. Hal ini disebabkan, usahatani tebu adalah usaha yang utama, sedangkan sapi yang diusahakan adalah sebagai tabungan petani yang dapat digunakan jika petani bermaksud untuk menambah lahan tebu, ataupun untuk keperluan yang lain. Sama halnya dengan yang disampaikan Handayani (2009), pendapatan usahatani yang didominasi oleh usahatani tanaman, baik dari usahatani lahan sawah maupun lahan kebun, menunjukkan bahwa penghasilan utama petani adalah dari bercocok tanam, sementara ternak merupakan usaha sampingan yang berfungsi sebagai tabungan. Namun, usaha ternak juga berkontribusi terhadap pendapatan petani, yaitu sebesar 12,32 persen untuk petani yang melaksanakan sistem integrasi dan 13,51 persen untuk petani yang tidak melaksanakan sistem integrasi tebu-sapi.

Selain penjelasan secara deskriptif, diperlukan juga penjelasan secara statistik. Oleh karena itu, perlu dilakukan analisis fungsi pendapatan. Fungsi pendapatan pada penelitian ini yaitu merupakan fungsi dari luas lahan tebu, jumlah ternak sapi yang dimiliki, jumlah tenaga kerja dalam keluarga, dan dummy sistem integrasi tebu-sapi. Hasil pendugaan fungsi pendapatan dapat dilihat pada Tabel 8. Nilai koefisien determinasi yang ditunjukkan dengan nilai $\mathrm{R}^{2}$ yaitu sebesar 0,567 , menunjukkan bahwa 56,7 persen variasi produksi sapi dapat dijelaskan oleh semua variabel yang ada dalam model fungsi pendapatan. Nilai koefisien dari masing-masing variabel menunjukkan nilai elastisitas dari masingmasing variabel tersebut. Semua variabel dalam model fungsi pendapatan, memberikan pengaruh positif terhadap pendapatan petani. Variabel luas lahan, jumlah sapi, dan tenaga kerja dalam keluarga memberikan pengaruh positif dan signifikan terhadap pendapatan petani tebu.

Tabel 8. Hasil Pendugaan Model Pendapatan

\begin{tabular}{ccccc}
\hline Variabel Input & $\begin{array}{c}\text { Parameter } \\
\text { Koefisien }\end{array}$ & Nilait & Nilaip & VIF \\
\hline Konstanta & 16,001 & 50,85 & 0 & \\
Luas Lahan (LL) & 0,715 & 6,414 & 0 & 1,05 \\
Jumlah Sapi (JS) & 0,48 & 4,506 & 0 & 1,07 \\
$\begin{array}{c}\text { Tenaga Kerja dalam } \\
\text { Keluarga (TKDK) } \\
\text { Dummy Penerapan }\end{array}$ & 0,308 & 1,561 & 0,124 & 1,02 \\
$\begin{array}{c}\text { Sistem Integrasi Tebu- } \\
\text { Sapi(DSI) }\end{array}$ & 0,075 & 0,485 & 0,63 & 1,01 \\
$\begin{array}{c}\text { Koefisien Determinasi } \\
\left(\mathrm{R}^{2}\right)\end{array}$ & 0.567 & & & \\
\hline & & & & \\
\hline
\end{tabular}

Luas lahan memiliki nilai elastisitas terbesar yang berarti bahwa perubahan luas lahan akan memberikan pengaruh paling besar terhadap perubahan pendapatan petani. Persentase kepemilikan luas lahan di atas 1 hektar adalah lebih besar untuk petani yang melaksanakan sistem integrasi tebu sapi yaitu sebesar 48,94 persen. Variabel jumlah sapi memiliki nilai elastisitas kedua terbesar setelah variabel luas lahan, yang berarti bahwa perubahan jumlah sapi akan memberikan pengaruh sebesar nilai elastisitasnya terhadap perubahan total pendapatan petani. Penambahan jumlah ternak sapi memberikan pengaruh yang besar terhadap peningkatan total pendapatan petani, seperti yang dijelaskan oleh Kusnadi et al. (2006).

Selain variabel luas lahan dan jumlah ternak sapi, juga terdapat variabel dummy penerapan sistem integrasi tebu-sapi yang memiliki tanda koefisien positif. Hasil ini menunjukkan bahwa pendapatan petani yang menerapkan sistem integrasi tebu-sapi lebih tinggi daripada petani yang tidak menerapkan sistem integrasi tebu-sapi, namun hasil tersebut tidak signifikan. Hal ini menunjukkan bahwa pendapatan dari petani yang menerapkan sistem integrasi tebusapi maupun yang tidak menerapkan sistem integrasi tebu-sapi, secara signifikan tidak terdapat perbedaan.

Berkaitan dengan hal tersebut maka terdapat faktor lain yang mempengaruhi hal tersebut, seperti cara berusahatani tebu dan atau cara pemeliharaan sapi oleh petani yang melaksanakan sistem integrasi tebu-sapi lebih efisien, daripada petani yang tidak melaksanakan sistem integrasi tebu-sapi. Hal ini terkait dengan perbedaan penggunaan input produksi antara petani yang menerapkan sistem integrasi tebusapi dan yang tidak menerapkan sistem integrasi tebu-sapi.

Persentase penggunaan input produksi untuk usahatani tebu lebih kecil untuk petani yang melaksanakan sistem integrasi tebu-sapi, dibandingkan petani yang tidak melaksanakan sistem integrasi (Tabel 7). Hal ini menyebabkan biaya produksi usahatani tebu untuk petani yang melaksanakan sistem integrasi tebu-sapi, lebih kecil daripada petani yang tidak melaksanakan sistem integrasi tebu-sapi, sehingga pendapatan petani juga menjadi lebih tinggi. Selain itu, terdapat faktor lain seperti frekuensi mengikuti penyuluhan yang lebih tinggi oleh petani yang melaksanakan sistem integrasi, sehingga menyebabkan produksi, penerimaan, dan pendapatan untuk usahatani tebu juga lebih tinggi bagi petani yang melaksanakan sistem integrasi tebu-sapi. Seperti yang dijelaskan oleh Situmorang (2013), penyuluhan merupakan salah satu faktor yang dapat meningkatkan produksi pertanian.

\section{SIMPULAN DAN SARAN}

Berdasarkan hasil penelitian maka dapat disimpulkan sebagai berikut: (1) produksi tebu dari petani yang menerapkan sistem integrasi tebu-sapi lebih rendah daripada petani yang tidak menerapkan sistem integrasi tebu-sapi, namun tidak signifikan; (2) produksi sapi dari petani yang menerapkan sistem 
integrasi tebu-sapi lebih rendah daripada petani yang tidak menerapkan sistem integrasi tebu-sapi; dan (3) pendapatan dari petani yang menerapkan sistem integrasi tebu-sapi lebih tinggi daripada petani yang tidak menerapkan sistem integrasi tebu-sapi, namun perbedaan pendapatan tersebut tidak signifikan.

\section{SARAN}

Beberapa hal yang dapat disarankan adalah sebagai berikut: (1) untuk meningkatkan produksi tebu, maka perlu diperhatikan penggunaan input produksi sehingga biaya produksi tebu dapat menjadi lebih rendah dan pendapatan menjadi lebih tinggi; (2) untuk meningkatkan produksi sapi, variabel ketersediaan pakan ternak perlu diperhatikan. Rumput masih menjadi sumber pakan hijauan utama, sehingga untuk memenuhi ketersediaanya, diperlukan pembuatan kebun rumput khusus pakan ternak. Selain itu, penggunaan pakan alternatif seperti pucuk tebu juga penting dalam meningkatkan produksi sapi. Namun, pucuk tebu yang digunakan sebagai pakan, sebaiknya diolah terlebih dahulu, sehingga perlu peran pemerintah dalam meningkatkan penguasaan teknologi dari petani seperti pemberian penyuluhan; (3) untuk meningkatkan pendapatan petani, selain melalui peningkatan produksi tebu dan sapi, juga dapat dilakukan dengan pemanfaatan limbah tebu dan kotoran sapi sebagai pendapatan tambahan. Pemanfaatan limbah dapat dilakukan melalui pengolahan limbah. Sama halnya dengan poin 1 dan 2, penguasaan teknologi diperlukan untuk mewujudkan hal tersebut, sehingga peran pemerintah sangat penting dalam pelaksanaan sistem integrasi tebu-sapi.

\section{DAFTAR PUSTAKA}

Achmad, F.A. 2011. Analisis Pendapatan Usahatani dan Faktor-faktor yang Mempengaruhi Produksi Susu Sapi Perah Peternak Desa Cibeureum Kabupaten Bogor. Skripsi. Institut Pertanian Bogor, Bogor.

Asmara, Alla. 2002. Optimalisasi Pola Usahatani Tanaman Pangan pada Lahan Sawah dan Ternak Domba di Kecamatan Sukahaji, Majalengka. Tesis. Institut Pertanian Bogor, Bogor.

BPS. 2012. Gorontalo dalam Angka. Gorontalo: Badan Pusat Statistik.

Devendra, C., Thomas, D., Jabbar, M.A., Kudo, H. 1997. Improvement of Livestock Production in Crop-Animal Systems in Rainfed Agroecological Zones of South-East Asia. Kenya: ILRI (International Livestock Research Institute), Nairobi.

Dinas Perkebunan dan Peternakan Provinsi Gorontalo. 2009. Laporan Tahunan Satuan Kerja (05, 07, 08, APBD) Sub Dinas Perkebunan (2009). Gorontalo: Dinas Perkebunan dan Peternakan Provinsi Gorontalo.
Direktorat Jenderal Peternakan dan Kesehatan Hewan. 2012. Pedoman Umum Pengembangan Integrasi Tanaman-Ruminansia. Jakarta: Direktorat Jenderal Peternakan dan Kesehatan Hewan, Republik Indonesia.

Direktorat Pengembangan Potensi Daerah. 2014. Potensi Tebu di Gorontalo. Jakarta: Badan Koordinasi Penanaman Modal

Elly, F.H., Sinaga, B.M., Kuntjoro, S.U., Kusnadi, N. 2008. Pengembangan Usaha Ternak Sapi Rakyat melalui Integrasi Sapi-Tanaman di Sulawesi Utara. Jurnal Litbang Pertanian, 27(2), 63-68.

Handayani, S. 2009. Model IntegrasiTtanamanTernak di Kabupaten Donggala Provinsi Sulawesi Tengah: Pendekatan Optimalisasi Program Linier. Tesis. Institut Pertanian Bogor, Bogor.

Hartoyo, S. 2013. The Impact of Rural Road Rehabilitation on Rice Productivity and Farmers Income in Kemang Village, Cianjur, West Java, Indonesia. J.ISSAAS, 19(2), 18-29.

Howara, D. 2004. Optimalisasi Pengembangan Usahatani Tanaman Padi dan Ternak secara Terpadu di Kabupaten. Tesis. Institut Pertanian Bogor, Bogor.

Indraningsih, Widiastuti, R., Sani, Y. 2006. Limbah Pertanian dan Perkebunan sebagai Pakan Ternak: Kendala dan Prospeknya. Lokakarya Nasional Ketersediaan IPTEK dalam Pengendalian Penyakit Stategis pada Ternak Ruminansia Besar, Bogor, Puslitbang Peternakan, hlm 99-115.

Kariyasa, K. 2005. Sistem Integrasi Tanaman-Ternak dalam Perspektif Reorientasi Kebijakan Subsidi Pupuk dan Peningkatan Pendapatan Petani. Analisis Kebijakan Pertanian, 3(1), 68-80.

Khairiah dan Wasito. 2007. Dampak Sistem Integrasi Padi dan Ternak dalam Rangka Pengembangan Ternak Sapi di Kabupaten Serdang Bedagai, Sumatera Utara. Seminar Nasional Teknologi Peternakan dan Veteriner, Bogor, Puslitbang Peternakan, Agustus 21-22, hlm 333-338.

Kusnadi, U., Juarini, E., Sajimin, Isbandi. 2006. Produktivitas dan Dampak Integrasi Ternak Domba Ekor Gemuk terhadap Pendapatan Petani dalam Sistem Usaha Sayuran di Lahan Marjinal. Seminar Nasional Teknologi Peternakan dan Veteriner, Bogor, Puslitbang Peternakan, September 5-6, hlm 419-424.

Kusnadi, U. 2008. Inovasi Teknologi Peternakan dalam Sistem Integrasi Tanaman-Ternak untuk Menunjang Swasembada Daging Sapi. Pengembangan Inovasi Pertanian, 1(3), 189-205.

Musa, Y.H., Onu, J.I., Vosanka, I.P., Anonguku, I. 2011. Production Efficiency of Yam in Zing Local Government Area of Taraba State, Nigeria. J of Hortic For, 3(12), 372-378. 
Priyanti, A. 2007. Dampak Program Sistem Integrasi Tanaman-Ternak terhadap Alokasi Waktu Kerja, Pendapatan, dan Pengeluaran Rumah tangga. Disertasi. Institut Pertanian Bogor, Bogor.

Puastuti, W. 2007. Pengolahan Kotoran Ternak dan Kulit Buah Kakao untuk Mendukung Integrasi Kakao-Ternak. Lokakarya Nasional Jejaring Litkaji Sistem Integrasi Tanaman-Ternak, Bogor, Puslitbang Peternakan, hlm 200-207.
Retnani, Y., Widiarti, W., Amiroh, I., Herawati, L., Satoto, K.B. 2009. Daya Simpan dan Palatabilitas Wafer Ransum Komplit Pucuk dan Ampas Tebu untuk Sapi Pedet. Media Peternakan, 32(2), 130-136.

Shehu, J.F., Iyortyer, J.T., Mshelia, S.I., Jongur, A.A.U. 2010. Determinants of Yam Production and Technical Efficiency among Yam Farmers in Benue State, Nigeria. J Soc Sci, 24(2), 143-148. 